\title{
DOES CHINA'S IRON ORE FUTURES MARKET HAVE PRICE DISCOVERY FUNCTION? ANALYSIS BASED ON VECM AND STATE-SPACE PERSPECTIVE
}

\author{
Yongbo $\mathrm{GE}^{1}$, Tingting $\mathrm{CAO}^{2 *}$, Ruchuan JIANG ${ }^{3}$, Peide $\mathrm{LIU}^{4}$, \\ Hengxin XIE ${ }^{5}$ \\ ${ }^{1}$ School of Finance, Shandong University of Finance and Economics, \\ 40, Shungeng Road, Jinan Shandong, China, 250001 \\ ${ }^{2}$ School of Economics and Management, Weifang University of Science and Technology, \\ 1299, Jinguang Street, Shouguang Shandong, China, 262700 \\ ${ }^{3}$ School of Business, China University of Political Science and Law, \\ 27, Fuxue Lu, Changping District, Beijing, China, 102249 \\ ${ }^{4}$ School of Management Science and Engineering, Shandong University of Finance \\ and Economics, 7366, Erhuandong Road, Jinan Shandong, China, 250014 \\ ${ }^{5}$ School of Statistics, Shandong University of Finance and Economics, \\ 7366, Erhuandong Road, Jinan Shandong, China, 250014
}

Received 26 February 2019; accepted 21 June 2019

\begin{abstract}
As the world's largest importer, trading of iron ore occupies a pivotal position in China's international trade. In order to seek the decision power of deciding the price for iron ore, China's Dalian Commodity Exchange (DCE) listed iron ore futures in October 2013, which has become the world's largest iron ore financial derivatives trading market now. Based on VECM and state-space perspective, this paper aims to explore the price discovery function of iron ore futures on the DCE. Comprehensive analysis from the views of long-term equilibrium relationship, short-term information shocks and dynamic contribution share are made in this paper. The empirical results show that: firstly, from the perspective of cointegration test, there is a long-term equilibrium relationship between the futures prices in DCE and the spot prices; secondly, when facing with short-term information shocks, iron ore futures in DCE have an obviously price discovery function by the analysis of impulse response and variance decomposition; finally, by the way of state-space and Kalman filter algorithm, the long-term equilibrium relationship dynamic contribution for price discovery function of DCE's iron ore futures remains stable between $60 \%$ and $70 \%$ now.
\end{abstract}

Keywords: price discovery, iron ore futures, VECM, state-space model, Kalman filter, dalian commodity exchange.

JEL Classification: G13, G14, G15.

\footnotetext{
*Corresponding author. E-mail: haiyictt@163.com
} 


\section{Introduction}

As one of the important fundamental industries of Chinese national economy, the steel industry plays a key role in the process of Chinese industrialisation and urbanisation. As the main material of the steel industry to the Chinese economy, the importance of iron ore is evident. At present, iron ore has become the second biggest industrial raw material, second only to crude oil. But because many of China's iron ores are lean ores and the exploration conditions are complicated, iron ores in China depend heavily on import. At present, China has become the largest global consumer and importer of iron ore, and the iron ore trade is taking a significant position in the international trade of bulk commodities in China. In 2017 the import of iron sand and its concentrate reached 1,075 million tons, 5\% higher than the previous year, and iron ore import dependence was above $85 \%$, which once again renewed the record of iron ore import for China. However, as the largest iron ore importer and consumer, China does not have the pricing rights of the spot trade for iron ore, even the pricing mechanism of iron ore is monopolised by the world's major mines over a long period of time.

The exertion of the price discovery function in the futures market is an important indicator to measure the efficiency and maturity of a country's futures market. This area is also one of the hot topics studied by the academic community. The listing of iron ore futures on the Dalian Commodity Exchange (DCE) is still in its infant stage, with relatively little academic research on the price discovery function of the DCE iron ore futures price, and the research methods are restricted to static time sequence calculation methods such as the Granger cause and effect testing, cointegration testing and the vector autoregression (VAR) model. Based on VECM and state-space perspective, this paper aims to explore the price discovery function since the listing of iron ore futures on the DCE to provide reference to theoretical circles and business circles. Comprehensive analysis from the views of long-term equilibrium relationship, short-term information shocks and dynamic contribution share are made in this paper.

The structure of this paper can be shown as follows. In this paper, firstly the evolution of the iron ore pricing mechanism in the spot market is introduced and a comparison made of the three main price indexes for iron ore in part one. It is noted that the Platts index has become the official index monopolised by the mining giants to determine the spot price of iron mineral. The futures markets of iron ore on a worldwide scale are introduced including the iron ore futures market on China's DCE, which has become the world's largest iron ore futures market. In the second part of this paper, the testing methods for price discovery function in the futures market are reviewed. The error correction model, the common factor model, the model of volatility spillover effect and the state-space model are explained. Thirdly, the different methods for price discovery function are compared and the VECM and state-space model were chosen in this paper based on the holding cost theory. In the fourth part of this paper, the closing price of dominant contracts of iron ore on the DCE are taken as the price index of iron ore futures, and the $62 \%$ Platts index is taken as the spot price index of iron mineral from 18 October 2013 to 20 March 2018. The empirical tests are from the points of long-term equilibrium relationship, short-term information shocks and dynamic contribution share. The VECM and state-space model shows that China's iron ore 
futures market currently contains a strong price discovery function both in short-term and dynamic view. In the part of conclusion, several important issues have been mentioned as future research topics.

\section{Evolution of iron ore pricing mechanism and introduction of futures trading of iron ore in China}

Before the 1950s, the global iron ore supply was sufficient with the spot transaction as the main trading method. In the 1960s, in order to satisfy the need of the fast-growing domestic industry, Japan became the major purchase party of the iron ore resources of Australia, with whom a long-term price locking contract was signed. In the 1970s, the United States (US) and various European countries followed Japan and signed long-term procurement agreements with the major mines. With continuing growth of the iron ore trade worldwide, and to uphold the monopoly benefit of the seller party itself, major iron ore export countries established the "Organization of Iron Ore Exporting Countries" to try to strengthen their bargaining power in iron ore negotiations by changing from long-term agreements to shortterm agreements. Under a long-term agreement between supply and demand parties, the iron ore is fixed in quantity but not fixed in price; the price is negotiated annually; supply and demand parties negotiate in the fourth quarter of every year; and the first transaction price between supply and demand parties will serve as the basic trade price for the next financial year, which will be identified with and followed by other traders. Under such a pricing mechanism, the iron ore supply and demand of the globe is generally balanced, and the price fluctuation is relatively smooth. Such a "starting-following" mode is favoured by both supply and demand parties.

With the current growth of the Chinese economy and constant progression of industrialisation and urbanisation, the iron ore import amount skyrocketed. In 2003 the iron ore import amount of China reached 148 million tons, exceeding Japan for the first time and making China the largest iron ore importer. In the same year, Baosteel, as the representative of Chinese steel enterprise, joined the iron ore annual agreement negotiation party for the first time. Currently, because of the existence of the iron ore import quota system in China, it is hard for small and medium steel enterprises to get an agreement share with major iron ore mines, and large quantities of agreement ore is resold at a higher price on the spot ore trade market. The three major global mines covet high profit of the current spot market of the iron ore trade and constantly seek the opportunity to break the pricing mechanism of annual agreements. In 2009, after Japanese and Korean steel factories identified the "starting price" of the three major mines, China single-handedly reached a procurement agreement of a lower price with FMG, the fourth largest global mine. In 2010, international iron ore giants headed by Vale SA, Rio Tinto and BHP successively announced the abandonment of the iron ore long-term agreement pricing mechanism and the implementation of quarter pricing, which marked the total breakdown of 30 years' of the annual agreement pricing mechanism. The trend of short-term pricing modes such as quarter pricing, month pricing and index pricing began to prevail. The basic process of the iron ore pricing mechanism is demonstrated in Table 1. 
Table 1. Evolution process of the iron ore pricing mechanism

\begin{tabular}{|l|l|}
\hline \multicolumn{1}{|c|}{ Time } & \\
\hline Before 1950 & Mainly spot transactions \\
\hline $1960-1974$ & Mainly long-term contracts \\
\hline $1975-1979$ & $\begin{array}{l}\text { "Organization of Iron Ore Exporting Countries" was founded, with the intention } \\
\text { of transforming long-term contracts to short-term contracts }\end{array}$ \\
\hline $1980-2002$ & Annual agreement pricing negotiation mechanism was established \\
\hline $2003-2007$ & $\begin{array}{l}\text { Baosteel participated in annual agreement pricing negotiation on behalf of } \\
\text { Chinese enterprise }\end{array}$ \\
\hline 2008 & The pricing rule of "starting-following" was broken \\
\hline 2009 & China single-handedly reached a low price procurement agreement with FMG \\
\hline 2010 & Annual agreement pricing negotiation mechanism broke apart \\
\hline 2011 and after & The trend of short-term pricing mode gradually prevailed \\
\hline
\end{tabular}

Index pricing gradually became the major settlement method for the spot trade of iron ore. There are three types of spot price index of iron ore with an international influence: the Platts index of Platts, the TSI index of Steel Business Briefing (SBB) and the MBIO index of MB (a detailed comparison of the pricing methods is detailed in Table 2).

The Platts index was officially introduced in June 2008 and adopted by BHP, the largest mining company in Australia, becoming the criterion for iron ore pricing around the globe. After April 2010, all the major mining giants refer to such an index in the iron ore export trade. At present, the Platts index has become the official index to determine the spot price of iron mineral. But such an index offers the heaviest weight to the pricing of the mining company while taking the quotation price not actually realised as the basis of the index price, therefore, the Platts index is generally the highest of the three indexes. In industrial circles it is generally believed that such a mechanism is unscientific and unreasonable, and that there is the possibility of manipulation by the mining giants.

With the shortening of the pricing cycle and increasing fluctuation in the global iron ore price, the risks are looming. In order to evade the price fluctuation risk and break the monopoly of the mining giants in the pricing of iron ore, many countries started to develop financial derivatives of iron ore. In January 2011, the third largest iron ore supplier, India, introduced the first iron ore futures with the TSI index as the settlement price. In August 2011, the Singapore Mercantile Exchange (SMX) introduced iron ore futures contracts with MBIO as the settlement price. In April 2013, the Singapore Exchange (SGX) introduced futures contracts with $62 \%$ grade iron ore price of the Tianjin port of China as the reference index. In May 2013, the Chicago Mercantile Exchange (CME) introduced swap futures with the Platts index, the TSI index, and low aluminium and low grade TSI index as the settlement basis. In order to capture the discourse power in the global iron ore pricing, the DCE listed iron ore futures contracts in October 2013. Since its listing, the trading volume, trading value and positions have gradually increased each year. At present the trading size of DCE's iron ore futures has been well ahead of the iron ore financial derivatives of other exchanges. The DCE is becoming the largest global iron ore financial derivative market. In 2017 the trading 
amount in iron ore futures on the DCE was 65.749 billion tons, compared to 1.78 billion tons on the SGX, the second largest iron ore financial derivative market. Table 3 details the DCE iron ore futures trading and positions.

Table 2. Comparison of the three iron ore price indexes

\begin{tabular}{|l|l|}
\hline Index & \multicolumn{1}{c|}{ Price quotation mechanism } \\
\hline $\begin{array}{l}\text { Platts } \\
\text { index }\end{array}$ & $\begin{array}{l}\text { Analysts of Platts in London and Singapore communicate with market partners } \\
\text { concerning the information of trade, inquiry and quotation through telephone and } \\
\text { instant messaging tools. At the end of every working day (Beijing time 18:30). Analysts } \\
\text { will evaluate the information collected before this time to the index price of the day. }\end{array}$ \\
\hline $\begin{array}{l}\text { TSI } \\
\text { index }\end{array}$ & $\begin{array}{l}\text { The actual transaction data of the day from 74 enterprises composed of mines, traders, } \\
\text { and steel factories is collected and calculation is made using weighted average method. } \\
\text { The formation of the index is based on actual trading price. On 28 June 2011 Platts } \\
\text { announced its purchase of SBB. }\end{array}$ \\
\hline $\begin{array}{l}\text { MBIO } \\
\text { index }\end{array}$ & $\begin{array}{l}\text { With 20-25 statistics sampling points selected, the calculation is made in accordance } \\
\text { with the actual transaction amount of the trading day weighted by tonnage. In the } \\
\text { calculation, quality, work site of refinery and quality of iron ore of different grades are } \\
\text { taken account. The three data sources of the index are: steel factories, mines and traders, } \\
\text { which respectively account for one third. Any data collected will be excluded if it is 4\% } \\
\text { higher or 4\% lower than the data of its weighted calculation. }\end{array}$ \\
\hline
\end{tabular}

Table 3. Iron ore futures trading volume, trading value and positions for the DCE

\begin{tabular}{|c|c|c|c|c|c|c|}
\hline \multirow{2}{*}{ Year } & \multicolumn{2}{|c|}{$\begin{array}{c}\text { Trading volume } \\
\text { (ten thousand) }\end{array}$} & \multicolumn{2}{c|}{$\begin{array}{c}\text { Trading value } \\
\text { (100 million yuan) }\end{array}$} & \multicolumn{2}{c|}{$\begin{array}{c}\text { Positions } \\
\text { (ten thousand) }\end{array}$} \\
\cline { 2 - 7 } & Yearly average & Daily average & Year average & Daily average & Yearly average & Daily average \\
\hline 2013 & 437.8 & 8.3 & 4088.7 & 77.1 & 676.6 & 12.8 \\
\hline 2014 & 19271.8 & 78.7 & 121010.9 & 472.7 & 21982.4 & 89.7 \\
\hline 2015 & 51914.4 & 212.8 & 197927.3 & 811.2 & 36939.6 & 151.4 \\
\hline 2016 & 68453.1 & 280.5 & 289560.7 & 1186.7 & 42504.4 & 174.2 \\
\hline 2017 & 65748.7 & 274.0 & 341589.08 & 1423.29 & 50266.2 & 209.4 \\
\hline
\end{tabular}

Note: every transaction $=100$ ton; transaction amount, transaction value and positions are calculated bilaterally.

\section{A review of the testing method of the price discovery function of the futures market}

According to holding cost theory, the price discovery function of the futures market refers to the futures price as the sum of the spot price and the holding price, without considering tax and trading costs. Holding costs include spot goods storage charges, transportation charges, insurance premiums and loan interest. Therefore, futures can reflect the expectation of supply and demand parties towards the trend futures price for which the futures price can precede and lead the spot price. However, the existence of friction in the real market causes a preceding and lagging relationship of prices between the futures and spot markets, as fric- 
tion levels in these markets may not be quite the same. It is generally believed that because a mature futures market is characterised by high leverage and low cost, its price can precede the spot price to reflect the newest market information. Therefore, the discovery level of the futures market price has become one of the indexes to measure the maturity and efficiency of futures markets.

Among the many literatures on the function of price discovery in the futures market, the definitions of price discovery fall into two broad categories. One view is that price discovery is a process that the futures market absorbs information and responds quickly through the changes of price. If the futures market reacts earlier than the spot market when facing the same new information shocks from the markets, then the futures market can guide the price trend of the markets and the futures market is considered to have a price discovery function (Garbade \& Silber, 1983). Another view is that price discovery is a process in which the futures market and the spot market look for long-term equilibrium of their prices for the same underlying commodity (Schreiber \& Schwartz, 1986). A mature futures market can guide the trend of the spot market in the long-term equilibrium trend with less trading friction and smoother flow of information compared to the spot market, thus a mature futures market exerting the function of price discovery. These two views explain the price discovery function of futures market respectively from the perspectives of short-term information shock and long-term equilibrium relationship. With the fast development of commodity futures in China, whether China's commodity futures market has a price discovery function and what level the price discovery function has reached. These become importance index to measure the maturity of the Chinese futures market. Researches about these topics are gradually becoming hot issues.

Based on the Granger causality test, Johansen (1988) and Johansen and Juselius (1990) proposed the cointegration test method, which was widely used in the research of the price discovery function in futures market and to measure the long-term equilibrium relationship between futures price and spot price. Based on cointegration analysis, there are four research methods of futures price discovery function: the error correction model, the common factor model, the model of volatility spillover effect and the state-space model.

\subsection{The error correction model}

The error correction model is mainly used in research on the first order moment of price. It depicts the response of futures and spot goods towards short-term price deviation, and investigates the influence of the short-term futures price on the price of spot goods from the view of short-term information shocks. Using the error correction model, Ghosh (1993), Tse (1995), Booth, So, and Tse (1999) and Lehmann (2002) respectively studied the price discovery function of S\&P 500 index futures in the US, Nikkei 225 stock index futures in Japan, DAX index futures of Germany, and copper futures of Europe and the US. Based on the error correction model and cointegration test, Liu and Chen (2017) found that there is a long-term and mutual guiding relationship between China's rebar futures market and the rebar spot market in North China, East China and Northeast China. Wang et al. (2017) based on the error correction model and cointegration test show that treasury bond futures 
are in the dominant position in price discovery function. Zou and Zhang (2018) based on the cointegration test and Granger causality test, construct a vector autoregressive model and use the impulse response function and variance decomposition method to analyze the mutual influence degree of international carbon futures price and China carbon price. Fang, Feng, Lu, and Wang (2019) according to the vector error correction principle, the influence of past market information on multiple market dynamic condition covariance matrices is analyzed, and a time-varying information share model is established to study the dynamic evolution of long-term price discovery function in China's steel market. Athanasios and Costas (2019) extend the study of price discovery and volatility transmission between the cash and futures index prices in Athens Exchange with the error correction model and the estimated information shares model.

\subsection{The common factor model}

The major method used to accurately calculate the price discovery contribution of futures and spot markets on the basis of the cointegration analysis method is the common factor model, which includes the information share model (IS) proposed by Hasbrouck (1995) and the permanent transitory model (PT) proposed by Gonzalo and Granger (1995). The IS and PT models both disintegrate impact influence to every market, and analyse the contribution of every market to the impact. The two models are closely related to each other, but their definitions of price discovery contribution are different. Baillie et al. (2002) discussed the differences between the two models. According to Baillie et al. (2002), the PT model disintegrates the common factor into a combination of two market prices, pays attention to the error correction mechanism in the model of vector correction error, and measures the contribution of every market to a common factor by defining the error correction coefficient. The IS model disintegrates variance of common factor, and measures the contribution of information of every market to common factor variance. Wang and Li (2016) used the PT model to investigate the price discovery function of aluminium futures on the Shanghai Stock Exchange. Xu and Rao (2018) used the PT model to quantitatively analyse the price discovery efficiency of iron ore futures in the Chinese market. Shi, Li, and Wang (2018) used the PT model and IS model to quantitatively analyse the price discovery efficiency of rebar futures in the Chinese market, in the long run the rebar spot market has contributed more to the price discovery function. Burcu and Jose (2019) collect data on futures and spot prices for the period December 2017 to May 2018 and compute information share model and common factor model component to quantify the contribution of each market to the price discovery process for the Bitcoin.

\subsection{The model of volatility spillover effect}

Bollerslev (1986) proposed the Generalised Autoregressive Conditional Heteroskedasticity (GARCH) model, which can seize characteristics of high frequency financial time sequences such as leptokurtosis and fat-tail, volatility clustering and conditional heteroskedasticity. At present, in terms of the research method, the volatility spillover effect model usually gives empirical analysis by using a multivariate GARCH model. Using a DCC-MGARCH and a 
VEC-BEKK-MGARCH model, Fu, Ji, and Zhong (2017) researched the continuous transaction system to the price co-movement between the Shanghai gold futures market and the US gold futures market. Xie and Yang (2018) used the VAR-BEKK-GARCH method to test and found that there was a certain volatility spillover effect between the spot market of the Shanghai and Shenzhen 300 stock indexes and the stock index futures market. Ding and Xiao (2018) empirically compared and analysed the spill over effects and dynamic correlation between the domestic and international cotton spot markets before and after the temporary purchasing policy and target price policy through the BEKK-GARCH model and the DCC-GARCH model. Zheng and Ma (2018) analyzed the spillover effects and dynamic correlation between the Chinese egg market in the spot market through the BEKKGARCH and DCC-GARCH models. Sun and Shi (2019) used the DCC-GARCH model to conduct a comparative study of the linkage between Shenzhen and Hong Kong stock markets by using the Shenzhen-Hong Kong Stock Connect as the time demarcation point.

\subsection{The state-space model}

Hamilton (1994) proposed the variable parameter state-space model of time sequence, which is another expression method for time sequence. By introducing the state-space model and the dynamic horizon of the Kalman Filter Algorithm into the research of futures price discovery function, $\mathrm{Wu}$ and $\mathrm{Ma}$ (2013) achieved the dynamic precision contribution to price discovery by futures price that changed with time. Huang, Liu, and Guo (2014) studied the contribution of price discovery in the Shanghai copper futures market from the dynamic perspective using the Kalman Filter Algorithm. The empirical result shows that the Shanghai copper futures market is in a dominant position in price discovery, but characterised with clear periodical volatility. Dang (2018) based on the Kalman filter algorithm, the price discovery function of rebar futures was measured. Bernardo et al. (2019) mentioned that Kalman filter is superior in both the estimation, without using a plug-in approach, and prediction for spatio-temporal data, providing a suitable formal procedure for the statistical analysis of space-time data.

\section{The VECM and state-space model for price discovery in the futures market}

\subsection{Why the VEMC and state-space model was chosen}

The function of price discovery in the futures market means that futures can reflect the expectation for the price trend both by the supply and requisitioning parties, so that futures prices can lead and guide spot prices. It is generally believed that the mature futures market has the characteristics of high leverage and low cost. The price in the futures market can lead the price in the spot market, and can also reflect the latest information. Therefore, the degree of futures price discovery becomes one of the indicators to measure the efficiency of the futures market. So, which method should be chosen to test the price discovery function of the futures market? Table 4 shows the advantages and disadvantages of several methods to test the price discovery function. 
Table 4. Comparison between methods for price discovery function

\begin{tabular}{|l|l|l|}
\hline \multicolumn{1}{|c|}{ Methods } & \multicolumn{1}{|c|}{ Advantages } & \multicolumn{1}{c|}{ Disadvantages } \\
\hline $\begin{array}{l}\text { Error correction } \\
\text { model }\end{array}$ & $\begin{array}{l}\text { Through the impulse response and } \\
\text { variance decomposition, VECM } \\
\text { can show the short-term impact of } \\
\text { information shocks on futures and } \\
\text { spot prices }\end{array}$ & $\begin{array}{l}\text { Only examines the impact of futures } \\
\text { prices on spot prices in the short- } \\
\text { term }\end{array}$ \\
\hline $\begin{array}{l}\text { Common factor } \\
\text { model }\end{array}$ & $\begin{array}{l}\text { Method of accurately determining } \\
\text { the contribution of price discovery in } \\
\text { both futures market and spot market }\end{array}$ & $\begin{array}{l}\text { Static method so only can get one } \\
\text { static contribution coefficient }\end{array}$ \\
\hline $\begin{array}{l}\text { Volatility spillover } \\
\text { effect model }\end{array}$ & $\begin{array}{l}\text { Used to study the two order moment } \\
\text { of yield and can characterise the } \\
\text { clustering characteristics of financial } \\
\text { returns }\end{array}$ & $\begin{array}{l}\text { Only explains the price discovery } \\
\text { problem from the perspective of } \\
\text { information dissemination }\end{array}$ \\
\hline State-space model & $\begin{array}{l}\text { A dynamic method that can calculate } \\
\text { the contribution of futures price } \\
\text { discovery accurately }\end{array}$ & $\begin{array}{l}\text { Can not show the short-term impact } \\
\text { of information shocks on futures and } \\
\text { spot prices }\end{array}$ \\
\hline
\end{tabular}

The application of the state-space model in the field of futures market price discovery function broke the limitations of previous model static analysis such as in the error correction model, the common factor model and the volatility spillover effect model, breaking new ground for research in this field. When the variable in the model is a non-observation variable, in order to estimate the parameters in the model, the best method to use is the Kalman Filter Algorithm, which is the powerful iterative algorithm. In the Kalman Filter Algorithm, the basic principle is to use a continuous time sequence of observation variables to continuously correct the value of non-observation variables, by which all unknown parameters contained in the model are estimated. The listing of iron ore futures on the DCE is still in its infant stage, where there is relatively little academic research on the price discovery function of iron ore futures, and the research methods are restricted in static time sequence calculation methods such as the Granger cause and effect testing, cointegration testing and the VAR model. Based on the holding cost theory, this paper uses the vector error correction model (VECM) firstly to investigate the price discovery function of iron ore futures in DCE from the view of short-term information shocks by the impulse response and variance decomposition. And then the dynamic price discovery function for iron ore futures in DCE will be measured from the view of state-space by using Kalman filter algorithm. The following questions will be answered in this paper. Firstly, from the perspective of cointegration test, is there a long-term equilibrium relationship between the futures prices in DCE and the Platts Index of iron ore which represents the spot trading prices? Secondly, when facing with short-term information shocks, what is the leadinglagging relationship between the iron ore futures price and the spot price when facing the short-term information shocks? Finally, based on VECM and from the view of state-space by using Kalman filter algorithm, the dynamic contribution for price discovery function of DCE iron ore futures will be displayed. 


\subsection{VECM and State-space view of futures price discovery function}

\subsubsection{Long-term equilibrium based on the holding cost theory}

Futures price is the expectation of price in commodities about to expire in the future. Futures price and spot price interact with each other through the arbitrage mechanism. According to the holding cost theory (Garbade \& Silber, 1983) the futures price of commodities are the sum of the spot price, storage costs in the contract period, capital costs and convenient benefit. This paper uses $S_{t}$ to represent the spot price of iron ore at time $t$ and $F_{t}$ to represent the corresponding logarithm of the futures contract price, with $T$ as the expiring time. The corresponding first order logarithm differences are recorded as $\Delta S_{t}$ and $\Delta F_{t}$ respectively, both of them are stationary time series, which are subject to the 0 order single-step process. Where $r$ represents average interest, $y_{t}$ represents convenient yield, which refers to possible benefits of investors holding spot price when spot goods have a risk premium on futures. Convenient benefit can be expressed as:

$$
y_{t}=\psi_{1} \times S_{t}-\psi_{2} \times F_{t} .
$$

The relationship between the futures price and the spot price when not considering tax and trade cost can be expressed as:

Balanced equation:

$$
F_{t}=S_{t}+r(T-t)-y_{t}
$$

$$
S_{t}=\beta_{1} \times F_{t}+\beta_{2}
$$

Among which:

$$
\beta_{1}=\frac{1-\psi_{1}}{1-\psi_{2}} ; \quad \beta_{2}=-r(T-t) .
$$

$S_{t}$ and $F_{t}$ are unstable time sequences, the two of them have cointegration relationship:

$$
\varepsilon_{t}=S_{t}-\beta_{1} \times F_{t}-\beta_{2} .
$$

Based on the above cointegration relationship, the Granger causality test proposed by Engle and Granger (1987), then the co-integration test method proposed by Johansen (1988) and Johansen and Juselius (1990) is a common method for testing the cointegration relationship between futures prices and spot prices.

\subsubsection{Short-term information impact on price disturbance}

Although the cointegration relationship shows that there is a long-term equilibrium relationship between the effective futures market and the spot market. However, in the real market, due to the existence of market friction, information will have a short-term impact on prices which leads to price deviations such as short-term price fluctuations and leading lag relationships. According to the Vector Error Correction Model (VECM), when there is a cointegration relationship between the futures price $F_{t}$ and the spot price $S_{t}$ there is an effective error correction term that can represent the short-term fluctuation of the price series and the long-term equilibrium information. The VECM model is as follows:

$$
\Delta F_{t}=m_{f}+\sum_{i=1}^{p}\left(\alpha_{f, i} \Delta F_{t-i}+\beta_{f, i} \Delta S_{t-i}\right)+\delta_{1, t} E C M_{t-1}+\varepsilon_{f, t}
$$




$$
\Delta S_{t}=m_{s}+\sum_{i=1}^{p}\left(\alpha_{s, i} \Delta F_{t-i}+\beta_{s, i} \Delta S_{t-i}\right)+\delta_{2, t} E C M_{t-1}+\varepsilon_{s, t} .
$$

In formulas (6) and (7), $\Delta F_{t}$ and $\Delta S_{t}$ are the first-order difference sequences of futures price $F_{t}$ and spot price $S_{t} ; \alpha_{f, i}, \alpha_{s, i}, \beta_{f, i}, \beta_{s, i}$ are short-term price adjustment coefficients, representing short-term disturbance terms of the cointegration equation; $\delta_{1, t}$ represents the long-term equilibrium adjustment factor of futures price; $\delta_{2, t}$ represents the long-term equilibrium adjustment factor of spot price; $\varepsilon_{f, t}, \varepsilon_{s, t}$ represent the residual term, which are a white noise sequences. The short-term leading-lagging effect between futures and spot prices can be expressed by the coefficients $\alpha_{f, i}, \alpha_{s, i}, \beta_{f, i}, \beta_{s, i}$. If the coefficients of $\alpha_{f, i}, \alpha_{s, i}, \beta_{f, i}, \beta_{s, i}$ are not all zero, then there is a short-term price guidance and forecast relationship between futures and spot. And the coefficients $\delta_{1, t}$ and $\delta_{2, t}$ represent the long-term equilibrium of futures market and spot market respectively. It can be seen that the price series can be decomposed into two parts: one part is reflected in the short-term price fluctuation caused by the short-term information shock, and the other part is the long-term dynamic equilibrium of the futures and spot price time series.

\subsubsection{Measurement of price discovery dynamic contribution}

Caporale et al. (2010) proposed that the price discovery contribution of futures price can be reflected by $\lambda$ which is the long-term error correction term in the VECM model, and the price discovery contribution of spot market is one minus $\lambda$ :

$$
\lambda=\frac{\left|\delta_{2, t}\right|}{\left(\left|\delta_{2, t}\right|+\mid \delta_{1, t}\right)} .
$$

On this basis, Harvey (1989), Hamilton (1994) adopted the idea of using state space equations, and introduced the variable parameter state space equation into the measurement of the coefficient $\lambda$ of the futures price discovery contribution. The model consists of two parts: the measurement equations (equation (6) and (7) in VECM) and the state equations. In order to estimate the parameter values in the model, the best method is to use the Kalman filter algorithm, which is a powerful iterative algorithm, to correct the error correction term of the long-term equilibrium relationship. The coefficients $\delta_{1, t}$ and $\delta_{2, t}$ in VECM are represented by the state space equation:

$$
\begin{aligned}
& \delta_{1, t}=\delta_{1, t-1}+\omega_{1, t} \\
& \delta_{2, t}=\delta_{2, t-1}+\omega_{2, t} .
\end{aligned}
$$$$
\text { state equation (9) }
$$$$
\text { state equation (10) }
$$

Kalman filtering is a recursive process for calculating the state variables in the state equation based on all available information at time $t$. Kalman filtering can calculate the likelihood function by predicting error decomposition, so that all unknown parameters of the model can be estimated. And once the new observations are obtained, the Kalman filter can be used to continuously correct the estimate of the state vector. 


\section{The empirical test for the DCE iron ore futures price discovery function}

\subsection{Descriptive statistics}

\subsubsection{Data selection and normality test}

Using the above theory, this paper uses data from 1,057 trading days of iron ore futures on the DCE from 18 October 2013 to 20 March 2018. The DCE closing price of the dominant contract of iron ore is used as the price index of iron ore futures. The $62 \%$ Platts index is used as the spot price index of iron mineral. In order to remove interference from the exchange rate, the data calculation is made by converting the closing price of the primary contract of iron ore mineral to US dollars in accordance with the USD-CNY spot exchange selling price published by the Bank of China on the day of the trading.

In order to decrease the possible heteroskedasticity of price sequence and increase precision of statistics, the spot price and the futures price are respectively given logarithm treatment, marked as $S_{t}$ and $F_{t}$, with the corresponding one order difference is marked as $\Delta S_{t}$ and $\Delta F_{t}$. Basic statistics characteristics of the research data is presented in Table 5.

Table 5. Futures and spot price and statistics of one order difference

\begin{tabular}{|c|c|c|c|c|c|c|c|}
\hline Variable & $\begin{array}{c}\text { Sample } \\
\text { number }\end{array}$ & $\begin{array}{c}\text { Average } \\
\text { value }\end{array}$ & $\begin{array}{c}\text { Standard } \\
\text { deviation }\end{array}$ & Deviation & Kurtosis & JB testing & P-value \\
\hline$S_{t}$ & 1.057 & 4.2664 & 0.3278 & 0.3898 & 2.25671 & 40.6559 & 0.000 \\
\hline$F_{t}$ & 1.057 & 4.3833 & 0.3311 & 0.4140 & 2.2097 & 45.9103 & 0.000 \\
\hline$\Delta S_{t}$ & 1.057 & -0.0008 & 0.0213 & 0.7360 & 11.8403 & 2814.50 & 0.000 \\
\hline$\Delta F_{t}$ & 1.057 & -0.0009 & 0.02324 & -0.8026 & 8.7505 & 1249.08 & 0.000 \\
\hline
\end{tabular}

Standard deviation reflects the dispersion tendency of variables. The standard deviation of spot goods, futures price and one order difference are given in Table 5. It can be seen that the volatility in the futures market is higher than that of the spot market. The deviations of spot price, futures price and one order difference are not zero, their kurtoses are close to 3, and the kurtoses after one order difference are larger than 3 . These show that the sequences do not obey normal distribution.

\subsubsection{Unit root and cointegration testing}

The ADF detection method is adopted to make unit root testing where intercept term and trend term are selected and the determination of the lag intervals for endogenous variable is based mainly on AIC criterion. The calculations and analyses are finished by the program Eviews 8.0. The unit root testing results are detailed in Table 6. From Table 4 it can be seen that $S_{t}$ and $F_{t}$ are unstable, while $\Delta S_{t}$ and $\Delta F_{t}$ are stable, that is $S_{t} \sim \mathrm{I}(1), F_{t} \sim \mathrm{I}(1)$.

From Table 6 it can be concluded that the ADF value of statistic volume $S_{t}$ and $F_{t}$ under $5 \%$ salience level are all larger than the $5 \%$ threshold level, showing that unit roots exist in the original sequences of both $S_{t}$ and $F_{t}$, which are unstable sequences. Through one order difference, the ADF testing statistics volume of both $\Delta S_{t}$ and $\Delta F_{t}$ are less than the $5 \%$ threshold value, showing that the one order difference sequence of both $S_{t}$ and $F_{t}$ have no unit root, therefore $\Delta S_{t}$ and $\Delta F_{t}$ are stable. 
Table 6. Unit root testing

\begin{tabular}{|c|c|c|c|c|l|}
\hline Variable & $\begin{array}{c}\text { ADF testing } \\
\text { t statistics }\end{array}$ & $\begin{array}{c}1 \% \text { threshold } \\
\text { value }\end{array}$ & $\begin{array}{c}5 \% \text { threshold } \\
\text { value }\end{array}$ & $\begin{array}{c}10 \% \text { threshold } \\
\text { value }\end{array}$ & \multicolumn{1}{|c|}{$\begin{array}{c}\text { Stability } \\
\text { testing }\end{array}$} \\
\hline$S_{t}$ & -1.3671 & -3.9690 & -3.4151 & -3.1297 & unstable \\
\hline$\Delta S_{t}$ & -25.4221 & -3.4379 & -2.8647 & -2.5685 & stable \\
\hline$F_{t}$ & -1.3565 & -3.9690 & -3.4151 & -3.1297 & unstable \\
\hline$\Delta F_{t}$ & -26.9503 & -3.4379 & -2.8647 & -2.5685 & stable \\
\hline
\end{tabular}

Table 7. Johansen cointegration testing

\begin{tabular}{|l|c|c|c|c|}
\hline Hypothesised no. of CE(s) & Eigenvalue & Trace statistic & 0.05 critical value & Prob. \\
\hline None & 0.026842 & 26.8887 & 15.4947 & 0.0006 \\
\hline At most 1 & 0.004790 & 4.0333 & 3.8414 & 0.0446 \\
\hline
\end{tabular}

From the Johansen cointegration testing (Table 7), it can be seen that according to the testing result of the trace statistic T0 $=26.8887>15.4947$, that is at the $5 \%$ salience level, " 0 cointegration relation" is denied; $\mathrm{T} 1=4.0333>3.8414$, that is at the $5 \%$ salience level, "there is at most one cointegration relation" is denied. Therefore, cointegration relationships exist between variables.

\subsection{Analysis of short-term price discovery of iron ore futures based on VECM}

According to the Johansen cointegration test, there is a first-order cointegration between the logarithmic price series of iron ore futures and the spot prices. Therefore, the vector error correction model (VECM) can be established to study the leading-lagging interaction and guidance relationships between them. Firstly, according to the AIC information criterion, the optimal lag order of the VECM model of iron ore futures and spot equilibrium relationship is 10 . That is to say, in equations (3) and (4) p takes the value 10.

\subsubsection{Impulse response analysis}

In Figure 1, DF represents one order difference of futures price and DS represents one order difference of spot price. Through the specific analysis of the impulse response map of iron ore (chart one), we can see that: firstly, the information shock and disturbance of iron ore from the futures market will not only affect the futures market price, but also the price of spot market. Among them, the futures market responded significantly and quickly to disturbances from the futures market. The spot market's response to information shocks and disturbances from the futures market was also significant. Secondly, the impact of iron ore information from the spot market only affects the spot market price, and the impact on the futures market is weak. The spot market responded significantly and quickly to information shocks and disturbances from the spot market. In short, the impact of one unit standard deviation of the iron ore futures market on the spot market is significant and the spot market is responding quickly. From the perspective of short-term and response to information shocks, iron ore futures in DCE have an obviously price discovery function. 
Response to Cholesky One S. D. Innovations for iron ore
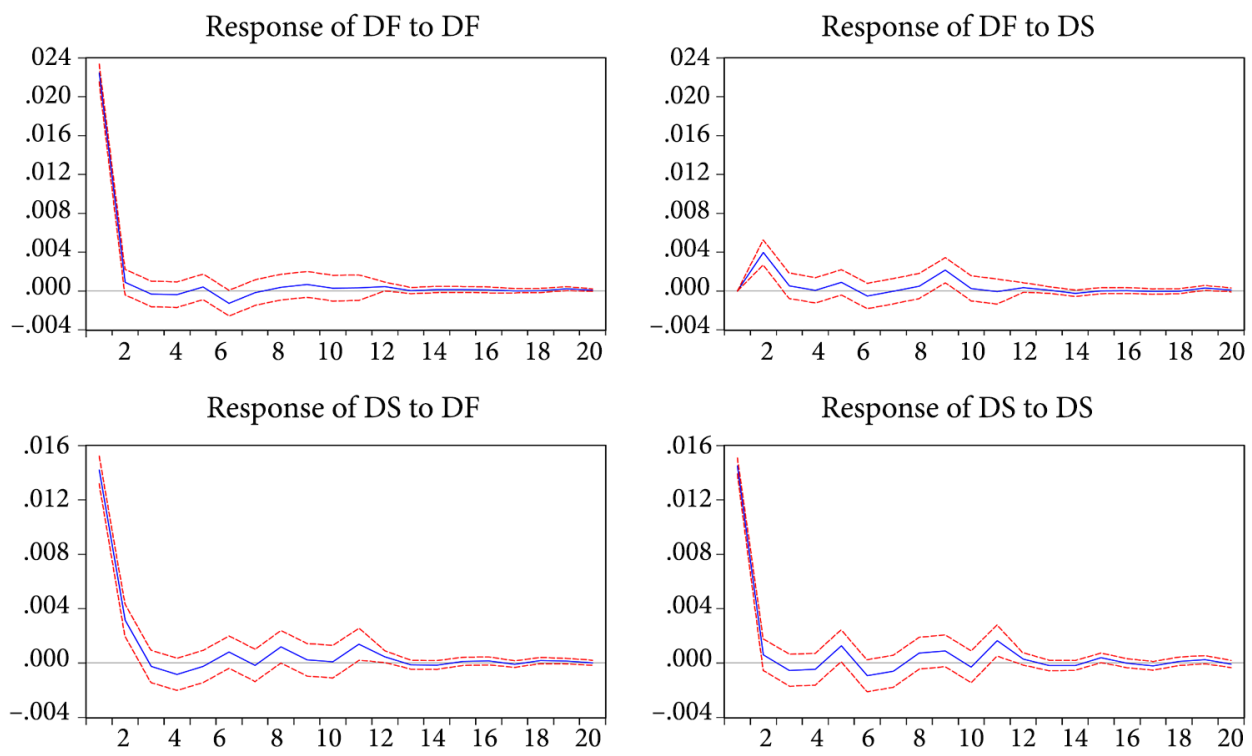

Figure 1. Impulse response map for iron ore futures and spot prices

\subsubsection{Variance decomposition}

In order to give the Information share of the futures price of iron ore in the price discovery function in the short-term, the decomposition of mean variance for iron ore futures price and spot price can be shown in Table 8 .

Table 8. Variance factor decomposition of based on VECM

\begin{tabular}{|c|c|c|c|c|}
\hline \multirow{2}{*}{$\begin{array}{c}\text { Lag } \\
\text { period }\end{array}$} & \multicolumn{2}{|c|}{ Variance decomposition of futures price } & \multicolumn{2}{c|}{ Variance decomposition of spot price } \\
\cline { 2 - 5 } & $\begin{array}{c}\text { Rate of } \\
\text { futures price }\end{array}$ & $\begin{array}{c}\text { Rate of } \\
\text { Spot price }\end{array}$ & $\begin{array}{c}\text { Rate of } \\
\text { futures price }\end{array}$ & $\begin{array}{c}\text { Rate of } \\
\text { Spot price }\end{array}$ \\
\hline 1 & 100.00 & 0.00 & 48.99 & 51.01 \\
\hline 2 & 96.99 & 3.01 & 50.15 & 49.85 \\
\hline 3 & 96.94 & 3.06 & 50.12 & 49.88 \\
\hline 4 & 96.94 & 3.06 & 50.18 & 49.82 \\
\hline 5 & 96.80 & 3.20 & 49.50 & 50.00 \\
\hline 6 & 96.75 & 3.25 & 49.97 & 50.03 \\
\hline 7 & 96.75 & 3.25 & 49.93 & 50.07 \\
\hline 8 & 96.71 & 3.29 & 50.04 & 49.96 \\
\hline 9 & 95.88 & 4.12 & 49.95 & 50.05 \\
\hline 10 & 95.87 & 4.13 & 49.94 & 50.06 \\
\hline 11 & 95.87 & 4.13 & 49.85 & 50.15 \\
\hline
\end{tabular}


From the above table it can be summarized: Firstly, making an Analysis of the variances which change iron ore futures price, the long-term stable contribution of squared difference of futures market is about $95.9 \%$, and the contribution of squared difference of spot market is about $4.1 \%$. Secondly, making an Analysis of the variances which change iron ore spot price, the long-term stable contribution of squared difference of futures market is about $50 \%$, and the contribution of squared difference of spot market is about $50 \%$. Therefore, from the perspective of price response to short-term information shocks, iron ore futures already have contributed a lot to the spot price and played an important role in price discovery function.

\subsection{Measurement of dynamic contribution of iron ore futures price discovery based on state space perspective}

On the basis of the VECM model, from the perspective of state space, using the Kalman filter iterative algorithm, the dynamic contribution coefficients of the price discovery of the futures price and the spot price in the long-term equilibrium relationship are graphically represented as Figure 2 to Figure 4.

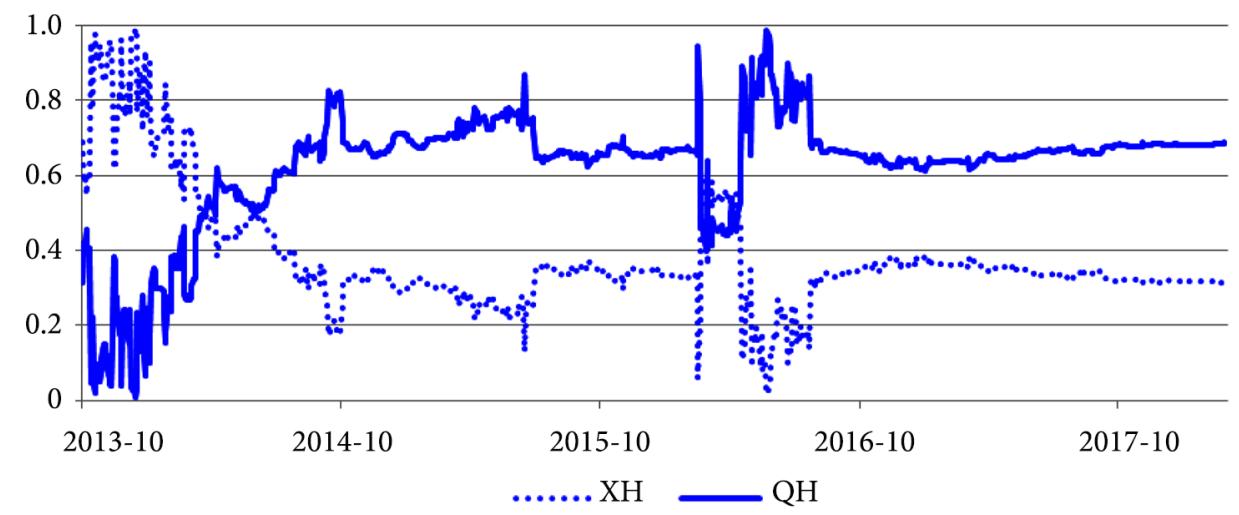

Figure 2. Contribution of price discovery in iron ore futures market $(\mathrm{QH})$ and spot market $(\mathrm{XH})$

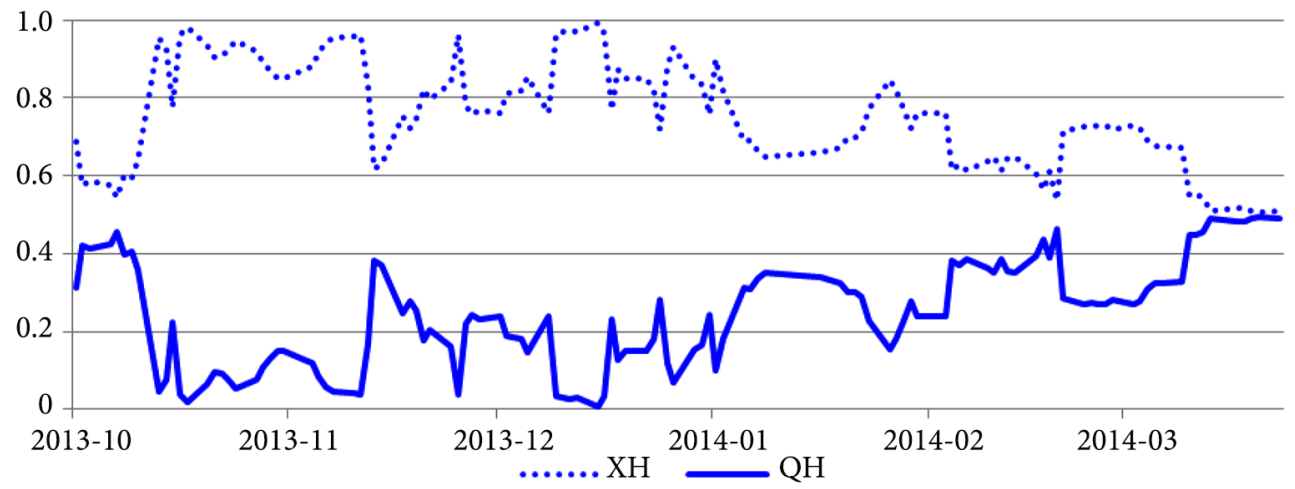

Figure 3. Contribution of price discovery in iron ore futures market $(\mathrm{QH})$ and spot market (XH) (time: 20131018-20140414) 


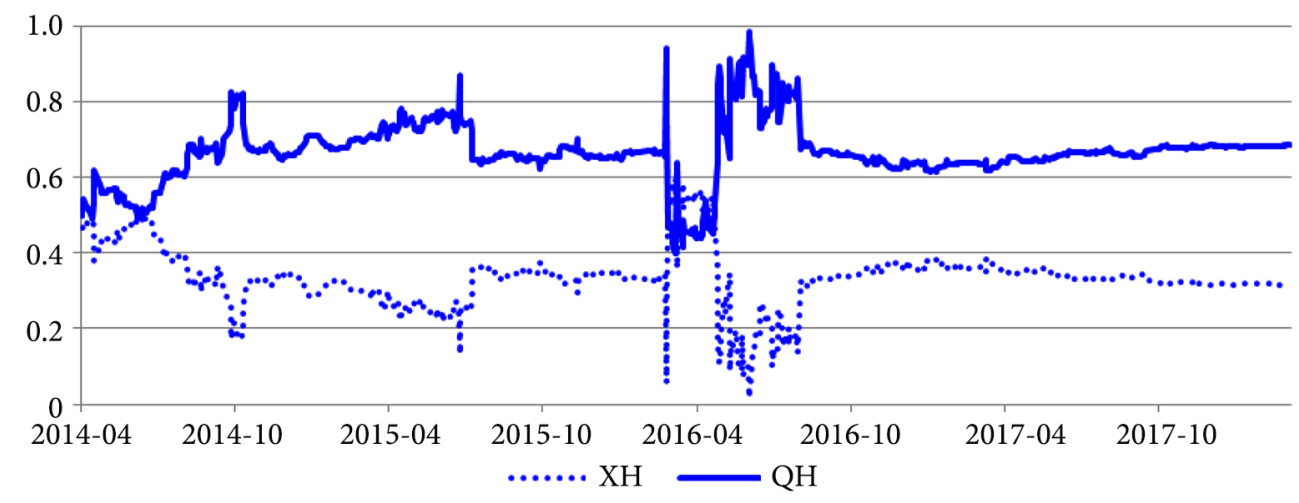

Figure 4. Contribution of price discovery in iron ore futures market $(\mathrm{QH})$ and spot market (XH) (time: 20140415-20180320)

$\mathrm{XH}$ represents the dynamic contribution trend of price discovery in the spot market and $\mathrm{QH}$ represents the dynamic contribution trend of price discovery in the futures market. From Charts 1 to 3, it can be seen that during October 2013 to April 2014, the contribution of the price discovery of the iron ore futures market on the DCE rose from less than $20 \%$ to around $50 \%$. The price discovery contribution in iron ore futures displays a fluctuating trend rising with time, but the spot price is still in the dominant position in the price discovery contribution. From April 2014 to April 2016, the price discovery contribution of the iron ore futures market on the DCE maintained above 50\%, and relatively stable. In the second and third quarters of 2016, the price discovery contribution displayed a violent volatility state. From the fourth quarter of 2016 to the present, the price discovery contribution of futures remains stable between $60 \%$ and $70 \%$. In general, since October 2013 when iron ore futures listed on the DCE, the price discovery function has gradually increased, and now China's iron ore futures contain a strong price discovery function.

As a new futures market, the iron ore futures market on the DCE is forming a good relationship with the spot market. Futures and spot prices interact with each other, and the DCE futures market of iron ore is playing an increasingly important role in the price discovery process. It shows that the iron ore futures market on the DCE is helpful for forecasting the spot price, which requires domestic and foreign iron and steel manufacturers to pay attention not only to the spot price of iron ore but also to the iron ore futures price on the DCE. In order to enhance the power of China in international trading for iron ore, full attention must be paid to the improvement of the trading mechanism in the futures market and the development of China's iron ore futures market.

\section{Conclusions}

In this paper, state-space model is constructed in accordance with the vector error correction model of cointegration testing, and the price discovery ability of the iron ore futures market on the DCE since its listing on 18 October 2013 has been studied. The three questions can be answered in this paper: Firstly, from the perspective of cointegration test, there is a long-term 
equilibrium relationship between the futures prices in DCE and the Platts Index of iron ore which represents the spot trading prices. Secondly, when facing with short-term information shocks, iron ore futures in DCE have an obviously price discovery function by the analysis of impulse response and variance decomposition. Finally, by the way of state-space and Kalman filter algorithm, the dynamic contribution for price discovery function of DCE's iron ore futures remain stable between $60 \%$ and $70 \%$ now. Hence, the price discovery function of the DCE iron ore futures market has been supported by the empirical evidence of this study.

In summary, this paper shows that the DCE iron ore futures market has gained a certain price discovery function now. However, there are also several deficiencies in the market system of the DCE iron futures market. Since as an important innovation, it has not worked for a long period of time. Firstly, for instance, the price of the DCE iron ore futures markets is still not the basic price in the international iron ore spot markets. Secondly, non-continuing problem of main contracts of iron ore futures also needs to be concerned in the DCE iron futures markets. These problems and deficiencies have shed light on the direction for the future studies. We will further research the topic that how to utilize the discovery function and expand the international influence of the DCE iron ore futures markets. Thirdly, this paper only focuses on the guiding relationship between the futures price and spot price from the state-space perspective based on the holding cost theory. This paper lacks a comparison of the price discovery function of iron ore futures between the Singapore exchange market and the Chinese exchange market. Fourthly, the futures price and spot price are not linked to volume, and there is no discussion of the relationship between volume and futures price. These potentially important issues have been left as future research topics.

\section{Funding}

This paper is funded by Major projects of The National Social Science Foundation of China (No. 18AJY021) and Major projects of The Social Science Foundation of Shandong Province (No. 17BJJJ09).

\section{References}

Athanasios, P. F., Costas, S. (2019). Intraday price discovery and volatility spillovers in an emerging market. International Review of Economics and Finance, 59, 333-346. https://doi.org/10.1016/j.iref.2018.09.008

Baillie, R. T., et al. (2002). Price discovery and common factor models. Journal of Financial Markets, 5(3), 309-321. https://doi.org/10.1016/S1386-4181(02)00027-7

Bernardo, L., Leonardo, P., Jorge, M., \& Guillermo, F. (2019). A Kalman filter method for estimation and prediction of space-time data with an autoregressive structure. Journal of Statistical Planning and Inference, 203, 117-130. https://doi.org/10.1016/j.jspi.2019.03.005

Bollerslev, T. (1986). Generalized autoregressive conditional heteroskedasticity. Journal of Econometrics, 31(3), 307-327. https://doi.org/10.1016/0304-4076(86)90063-1

Booth, G., So, R., \& Tse, Y. (1999). Price discovery in the German equity index derivatives markets. Journal of Futures Markets, 6, 619-643.

https://doi.org/10.1002/(SICI)1096-9934(199909)19:6<619::AID-FUT1>3.0.CO;2-M 
Burcu, K., \& Jose, O. (2019). An analysis of price discovery between Bitcoin futures and spot markets. Economics Letters, 1, 62-64. https://doi.org/10.1016/j.econlet.2018.10.031

Caporale, G. M., Ciferri, D., \& Girardi, A. (2010). Time-varying spot and futures oil price dynamics. Scottish Journal of Political Economy, 3(61). https://doi.org/10.2139/ssrn.1633862

Dang, H. Q. (2018). Research on the dynamic efficiency of price discovery in the rebar futures market. Dissertation for the Master Degree in Harbin Institute of Technology, 6.

Ding, C. Z., \& Xiao, H. F. (2018). On spillover effects and correlation between domestic and international cotton futures market: A comparative analysis under different policy backgrounds. Journal of Central South University (Social Science), 9, 117-128.

Engle, R. F., \& Granger, C. W. (1987). Co-integration and error correction: Representation estimation and testing. Econometrica, 2, 251-276. https://doi.org/10.2307/1913236

Fang, W., Feng, G. Z., Lu, F. B., \& Wang, S. Y. (2019). Research on dynamic evolution of price discovery in China's steel trading market. Systems Engineering Theory \& Practice, 1, 51-61.

Fu, Q., Ji, J. W., \& Zhong, H. Y. (2017). Continuous trading system and price discovery ability-based on China's gold futures market. Journal of Applied Statistics and Management, 6, 1119-1130.

Garbade, K. D., \& Silber, W. L. (1983). Price movements and price discovery in futures and cash markets. The Review of Economics and Statistics, 65(2), 289-297. https://doi.org/10.2307/1924495

Ghosh, A. (1993). Cointegration and error correction models: Intertemporal causality between index and futures prices. Journal of Futures Markets, 13(2), 193-198. https://doi.org/10.1002/fut.3990130206

Gonzalo, J., \& Granger, C. (1995). Estimation of common long-memory components in cointegrated systems. Journal of Business \& Economic Statistics, 13(1), 27-35. https://doi.org/10.1080/07350015.1995.10524576

Hamilton, J. D. (1994). A new approach to the economic analysis of nonstationary time series and the business cycle. Econometric Reviews, 57, 357-384. https://doi.org/10.2307/1912559

Harvey, A. (1989). Forecasting structural time series models and the Kalman filter. Cambridge University Press. https://doi.org/10.1017/CBO9781107049994

Hasbrouck, J. (1995). One security, many markets: Determining the contributions to price discovery. Journal of Finance, 50(4), 1175-1199. https://doi.org/10.1111/j.1540-6261.1995.tb04054.x

Huang, J. B., Liu, K., \& Guo, Y. Q. (2014). An empirical study on dynamic contribution of price discovery in Shanghai copper futures market-based on the state-space model. Journal of Technical Economics \& Management, 2, 67-72.

Johansen, S. (1988). Statistical analysis of cointegrating vectors. Journal of Economic Dynamics and Control, 12, 213-254. https://doi.org/10.1016/0165-1889(88)90041-3

Johansen, S., \& Juselius, K. (1990). Maximum likelihood estimation and inference on cointegration: with application to the demand for money. Oxford Bulletin of Economics and Statistics, 52, 169-210. https://doi.org/10.1111/j.1468-0084.1990.mp52002003.x

Lehmann, B. N. (2002). Some desiderata for the measurement of price discovery across markets. Finance Market, 5, 259-276. https://doi.org/10.1016/S1386-4181(02)00025-3

Liu, H. Z., \& Chen, Y. (2017). Research on the price discovery ability of rebar futures market in ChinaBased on different regional spot market. Price: Theory \& Practice, 10, 115-118.

Schreiber, P. S., \& Schwartz, R. A. (1986). Price discovery in securities markets. Journal of Portfolio Management, 12(4), 43-48. https://doi.org/10.3905/jpm.1986.409071

Shi, B. F., Li, A. W., \& Wang, J. (2018). Price discovery on Chinese rebar futures market. Operations Research and Management Science, 6, 162-171. 
Song, B., \& Xing T. C. (2018). Comparative study on the influence of China's Shanghai copper, LME copper and COMEX copper futures markets-analysis of dynamic relationship based on price discovery and spill over effect. Price: Theory \& Practice, 3, 127-130.

Sun, M., \& Shi, B. J. (2019). Research on Shenzhen-Hong Kong stock market linkage and risk spill over effect before and after the implementation of Shenzhen-Hong Kong stock connect. Journal of North China University of Science and Technology (Social Science Edition), 2, 55-61.

Tse, Y. K. (1995). Nonlinear dynamics of the Nikkei Stock Average Futures. Financial Engineering and the Japanese Markets, 2(3), 181-195. https://doi.org/10.1007/BF02425195

Wang, S. S., Yu, Y. R., Liu, H. M., \& Kang, Y. B. (2017). Research into price discovery of Chinese treasury bond futures based on high frequencies data. Operations Research and Management Science, 6, 117-123.

Wang, B. J., \& Li, A. W. (2016). Night trading and linkage between China and USA futures markets: from the perspective of volatility spillover effect and dynamic correlation. Financial Economics Research, 5, 65-74.

Wu, L., \& Ma, J. L. (2013). A systematic analysis of price discovery measures. China Economic Quarterly, 13(1), 399-424.

Xie, S. Q., \& Yang, W. T. (2018). Empirical test of spot price discovery function in high frequency stock index futures. Statistics \& Decision, 4, 148-152.

$\mathrm{Xu}$, C. S., \& Rao, S. S. (2018). Discovery efficiency and dynamic changes of prices in China's iron ore futures market. Journal of Jiangxi University of Finance and Economics, 1, 20-29.

Zheng, Y., \& Ma, J. (2018). Study on the spillover effect and dynamic relationship between egg futures market and spot market in China. Journal of China Agricultural University, 23, 222-231.

Zou, S. H., \& Zhang, T. (2018). International relationship between international carbon future price and domestic carbon price. Journal of Shandong University (Natural Science), 5, 70-79. 